\title{
Evaluation of lower-starch diets for lactating Holstein dairy cows
}

\author{
H. M. Dann, ${ }^{* 1}$ H. A. Tucker, ${ }^{*}$ K. W. Cotanch, ${ }^{*}$ P. D. Krawczel, ${ }^{* 2}$ C. S. Mooney, ${ }^{* 3}$ R. J. Grant, ${ }^{*}$ and T. Eguchi† \\ *William H. Miner Agricultural Research Institute, Chazy, NY 12921 \\ †Zen-Noh National Federation of Agricultural Cooperative Associations, 100-6832 Tokyo, Japan
}

\section{ABSTRACT}

The objective of this experiment was to measure ruminal and lactational responses of Holstein dairy cows fed diets containing 3 different starch levels: 17.7 (low; LS), 21.0 (medium; MS), or 24.6\% (high; HS). Twelve multiparous cows $(118 \pm 5 \mathrm{~d}$ in milk) were assigned randomly to dietary treatment sequence in a replicated $3 \times 3$ Latin square design with 3 -wk periods. All diets were fed as total mixed rations and contained approximately $30.2 \%$ corn silage, $18.5 \%$ grass silage, and $5.0 \%$ chopped alfalfa hay. Dietary starch content was manipulated by increasing dry ground corn inclusion (\% of dry matter) from 3.4 (LS) to 10.1 (MS) and 16.9 (HS) and decreasing inclusion of beet pulp and wheat middlings from 6.7 and 13.4 (LS) to 3.4 and 10.1 (MS) or 0 and 6.8 (HS). In vitro 6 -h starch digestibility of the diet increased as nonforage sources of fiber replaced corn grain (\% of dry matter; 73.6, HS; 77.3, MS; 82.5, LS) resulting in rumen-fermentable starch content by 14.6, 16.2, and $18.1 \%$ for the LS, MS, and HS diets, respectively. Diets had similar neutral detergent fiber from forage and particle size distributions. Dry matter intake, solids-corrected milk yield, and efficiency of solids-corrected milk production were unaffected by diet, averaging $26.5 \pm 0.8,40.8 \pm 1.6$, and $1.54 \pm 0.05 \mathrm{~kg} / \mathrm{d}$, respectively. Reducing dietary starch did not affect chewing time $(815 \pm 23 \mathrm{~min} / \mathrm{d})$, mean ruminal $\mathrm{pH}$ over $24 \mathrm{~h}(6.06 \pm 0.12)$, acetate-to-propionate ratio $(2.4 \pm$ $0.3)$, or microbial $\mathrm{N}$ synthesized in the rumen $(585 \pm 24$ $\mathrm{g} / \mathrm{d}$ ). Total tract organic matter digestibility was higher for HS compared with MS and LS diets (69.2, 67.3, and $67.0 \%$, respectively), but crude protein, neutral detergent fiber, and starch digestibilities were unaffected. As dietary starch content decreased, in vitro ruminal starch fermentability increased and, consequently, the range between HS and LS in rumen-fermentable starch (3.5 percentage units) was less than the range in starch content (6.9 percentage units). Under these conditions,

Received May 8, 2014.

Accepted August 10, 2014.

${ }^{1}$ Corresponding author: dann $@$ whminer.com

${ }^{2}$ Current address: University of Tennessee, Knoxville 37996.

${ }^{3}$ Current address: Morrisville State College, Morrisville, NY 13408. dietary starch content had no measurable effect on ruminal fermentation or short-term lactational performance of high-producing Holstein dairy cows.

Key words: starch, lactation performance, dairy cow

\section{INTRODUCTION}

The price for corn grain as a livestock feed approximately doubled between 2008 and 2013 (USDAEconomic Research Service, 2013). Consequently, lower starch-feeding strategies that minimize inclusion of corn and other grains may improve farm profitability, particularly if cow performance is not compromised. Chase (2007) summarized several surveys of highly productive dairy herds in the United States and found that dietary starch content typically ranged between 20 and $27 \%$, with few high-producing herds less than $20 \%$ starch.

Ruminal microbes require a supply of ruminally fermentable carbohydrates for growth and protein synthesis. Starch provides a substrate for microbial growth and greater ruminal degradability of starch, typically increasing flow of microbial protein to the duodenum (Firkins et al., 2001). However, sugars, digestible NDF, and soluble fiber ferment in the rumen and contribute to microbial protein production as well. For example, Hall and Herejk (2001) observed in vitro that sucrose and pectin supported 86 to $88 \%$ of the microbial protein production of starch.

A recent meta-analysis (Ferraretto et al., 2013), which included 414 treatment means from 102 papers published between 2000 and 2011, concluded that DMI is not affected by dietary starch content, whereas milk yield tends to increase $0.08 \mathrm{~kg} / \mathrm{d}$ for each percentage unit increase in starch content of the diet. Though milk yield minimally increases with increased dietary starch, no significantly greater feed conversion exists, suggesting that starch content may vary substantially with minimal effect on lactational performance (Ferraretto et al., 2013). However, previous studies are not in agreement with how starch content alters feed conversion and whether that is influenced by dietary ingredients. A recent study by Ferraretto et al. (2011) observed decreased efficiency with decreased dietary starch, whereas Gencoglu et al. (2010) found no effect of starch on efficiency, suggesting that animal responses 
may possibly differ with dietary ingredients and dietary starch content.

Many nonforage fiber sources (NFFS) are characterized by low starch content, high fiber digestibility, and variable soluble fiber and sugar content. These NFFS can replace a considerable portion of the corn grain in lactation diets without detrimental effects on production. Soybean hulls have been substituted for up to $97.5 \%$ of dietary corn with no effect on efficiency of FCM production (Ipharraguerre and Clark, 2003). Similarly, corn grain content has varied from 27 to $0 \%$ of dietary DM by substitution with wet corn gluten feed with no effect on 4\% FCM production (Boddugari et al., 2001). One limitation with many of these NFFS studies has been the moderate level of milk production. For example, milk production averaged only $30 \mathrm{~kg} / \mathrm{d}$ in the studies of Boddugari et al. (2001) and Ipharraguerre and Clark (2003). It may be inappropriate to infer these results to lower corn and lower-starch diets fed to high-producing dairy cows. Additionally, Bradford and Mullins (2012) suggest that current nutritional models inaccurately and imprecisely predict energy supply from NFFS. This is further complicated by the variability associated with NFFS and inability of current models to account for the associative effects within diets that are a key component of modeling energy supply with these unique diets (Bradford and Mullins, 2012).

Two common and potentially economical NFFS are wheat middlings and beet pulp. Little research with wheat by-products has been conducted with dairy cows, so optimal ration content is unknown (Blasi et al., 1995). But Voelker and Allen (2003a, b) evaluated the substitution of beet pulp for high-moisture corn at levels ranging from 6.1 to $24.3 \%$ of ration DM. As the content of corn in these diets decreased from 35.6 to $11.4 \%$ of ration DM, dietary starch content decreased from 34.6 to $18.4 \%$ of DM. Addition of beet pulp did not influence milk yield, although ruminal fiber digestion improved with no change in starch digestion. To date, no research has evaluated the ruminal and productive responses of high-producing cows when fed diets containing a range of dietary starch achieved by replacing corn grain with wheat middlings and beet pulp.

The objective of the current study was to measure the ruminal and short-term lactational responses of high-producing Holstein dairy cows when fed diets containing approximately 18 to $25 \%$ starch, a range commonly fed in the US dairy industry. This range in dietary starch was achieved by substituting beet pulp and wheat middlings for corn grain. We hypothesized that replacement of corn grain with NFFS within these concentrations of dietary starch would not alter ruminal function or short-term lactational performance.

\section{MATERIALS AND METHODS}

\section{Animal Use and Handling}

Twelve multiparous Holstein cows (3 ruminally fistulated) averaging $118 \pm 5 \mathrm{DIM}$ and $2.5 \pm 0.5$ lactations were housed in a tiestall facility at the William H. Miner Agricultural Research Institute (Chazy, NY). Cows were stratified by parity and milk production and then assigned randomly to dietary treatment sequence in a replicated $3 \times 3$ Latin square design with 3 -wk periods. Within each 3 -wk period, the first $14 \mathrm{~d}$ served as an adaptation period and the last $7 \mathrm{~d}$ were used for data collection. All squares were conducted concurrently. Animal care and handling protocols were approved by the William H. Miner Agricultural Research Institute Animal Care and Use Committee.

\section{Diet Formulation}

Cows were fed 3 diets (Table 1) formulated to range in starch content from approximately 18 to $25 \%$ (DM basis). Diets were formulated to supply adequate ME and protein for a cow 120 DIM with BCS of 3.0, BW of $703 \mathrm{~kg}$, DMI of $27 \mathrm{~kg} / \mathrm{d}$, and milk yield of $45 \mathrm{~kg} / \mathrm{d}$ containing $3.6 \%$ fat and $3.0 \%$ true protein using the CPM-Dairy nutrition model (ver. 3.0; Cornell University, Ithaca, NY; University of Pennsylvania, Philadelphia, PA; and William H. Miner Agricultural Research Institute, Chazy, NY). Diets contained similar amounts of corn silage (30\%), grass silage (18\%), and alfalfa hay (5\%; Tables 1 and 2). Starch content of the diets was varied by the inclusion rate of corn meal, which was $3.4,10.1$, and $16.9 \%$ of the lower (LS), medium (MS), and higher (HS) starch diets, respectively (Table 1). As corn was reduced, the dietary inclusion rate of beet pulp and wheat middlings increased.

Diets were delivered as TMR once daily (1030 h; Calan Data Ranger; American Calan Inc., Northwood, $\mathrm{NH}$ ) in amounts to ensure ad libitum access to feed. Dry matter intake was determined daily by difference between feed offered and refused for each cow during each data collection period.

\section{Milk Production and Composition}

Cows were removed from the barn 3 times daily $(0430,1230$, and $2030 \mathrm{~h})$ for milking in a double-12 parallel milking parlor (Xpressway Parallel Stall System; Bou-Matic, Madison, WI). Milk yields were recorded electronically (ProVantage Information Management System; Bou-Matic) on d 15 to 21 of each period. Milk samples from 3 consecutive milkings for each cow were collected on d 18 of each period. The 3 consecutive milk 
Table 1. Ingredient composition of low-, medium-, and high-starch diets fed to lactating Holstein cows

\begin{tabular}{|c|c|c|c|}
\hline \multirow[b]{2}{*}{ Ingredient, $\%$ of DM } & \multicolumn{3}{|c|}{ Dietary starch content } \\
\hline & Low & Medium & High \\
\hline Corn silage & 30.2 & 30.2 & 30.4 \\
\hline Grass silage & 18.5 & 18.5 & 18.6 \\
\hline Alfalfa hay & 5.0 & 5.0 & 5.1 \\
\hline Wheat middlings & 13.4 & 10.1 & 6.8 \\
\hline Distillers grain with solubles & 9.7 & 8.7 & 7.6 \\
\hline Soybean meal, $48 \%$ CP & 7.1 & 7.9 & 8.4 \\
\hline Beet pulp & 6.7 & 3.4 & - \\
\hline Corn meal & 3.4 & 10.1 & 16.9 \\
\hline Calcium carbonate & 1.6 & 1.6 & 1.6 \\
\hline Molasses & 1.3 & 1.3 & 1.3 \\
\hline Sodium bicarbonate & 1.0 & 1.0 & 1.0 \\
\hline AminoPlus $^{1}$ & 0.84 & 0.84 & 0.84 \\
\hline Rumen-inert fat ${ }^{2}$ & 0.42 & 0.42 & 0.42 \\
\hline Urea & 0.25 & 0.34 & 0.42 \\
\hline Sodium chloride & 0.17 & 0.17 & 0.17 \\
\hline Availa- $4^{3}$ & 0.14 & 0.14 & 0.14 \\
\hline Magnesium oxide & 0.13 & 0.13 & 0.13 \\
\hline Selenium ${ }^{4}$ & 0.06 & 0.06 & 0.06 \\
\hline Organic trace minerals ${ }^{5}$ & 0.04 & 0.04 & 0.04 \\
\hline Alimet $^{6}$ & 0.03 & 0.03 & 0.03 \\
\hline Vitamins $\mathrm{A}, \mathrm{D}$, and $\mathrm{E}^{7}$ & 0.02 & 0.02 & 0.02 \\
\hline \multicolumn{4}{|c|}{${ }^{1} \mathrm{Ag}$ Processing Inc., Omaha, NE. } \\
\hline \multicolumn{4}{|c|}{${ }^{2}$ Cargill Inc., Minneapolis, MN. } \\
\hline \multicolumn{4}{|c|}{${ }^{3}$ Zinpro Corp., Eden Prairie, MN. } \\
\hline \multicolumn{4}{|c|}{${ }^{4}$ Contained $606 \mathrm{mg}$ of $\mathrm{Se} / \mathrm{kg}$ and $36.4 \% \mathrm{Ca}$. } \\
\hline \multirow{2}{*}{\multicolumn{4}{|c|}{$\begin{array}{l}{ }^{5} \mathrm{Contained} 1.0 \% \mathrm{Ca}, 8.8 \% \mathrm{~S}, 4,102 \mathrm{mg} \text { of } \mathrm{Fe} / \mathrm{kg}, 2,045 \mathrm{mg} \text { of } \mathrm{Zn} / \mathrm{kg}, 20,425 \mathrm{mg} \text { of } \mathrm{Cu} / \mathrm{kg}, 31,681 \mathrm{mg} \text { of } \mathrm{Mn} / \\
\mathrm{kg}, 1,549 \mathrm{mg} \text { of } \mathrm{Co} / \mathrm{kg} \text {, and } 1,419 \mathrm{mg} \text { of } \mathrm{I} / \mathrm{kg} \text {. }\end{array}$}} \\
\hline \multicolumn{2}{|c|}{${ }^{6}$ Novus International Inc., St. Louis, MO. } & & \\
\hline${ }^{7}$ Contained $74,960 \mathrm{kIU}$ of vite & kIU o & & $\mathrm{E} / \mathrm{k}$ \\
\hline
\end{tabular}

samples were composited in proportion to milk yield at each sampling and preserved (Bronolab-W II Liquid Preservative; D\&F Control Systems Inc., Dublin, CA). Composited milk samples were analyzed for fat, true protein, lactose, SNF, urea nitrogen, and somatic cells by infrared procedures (Dairy One, Ithaca, NY; Foss 4000, Foss Technology, Eden Prairie, MN). Somatic cell score was calculated using $\left\{\left[\log _{10}(\mathrm{SCC} \div 1000)-2\right] \div\right.$ $\left.\log _{10}(2)\right\}+3$.

\section{Calculations of Efficiency}

Daily milk production was used to calculate the short-term response in 3.5\% FCM and SCM using NRC equations (NRC, 2001). Feed efficiency $(\mathrm{kg} / \mathrm{kg})$ was calculated and expressed as milk per unit of DMI, $3.5 \%$ FCM per unit of DMI, and SCM per unit of DMI for d 18 (sample day) of each period.

\section{$B W$ and $B C S$}

Body weight was measured (JR3000 indicator and MP600 58.4-cm load bars; Tru-Test Inc., Mineral Wells, TX,) and BCS was assigned in 0.25-unit increments on a 1 to 5 scale (Ferguson et al., 1994) for each cow at the beginning of the experiment and the end of each period $(1130 \mathrm{~h})$. Two individuals assigned BCS independently at each time of scoring throughout the experiment.

\section{Measures of Chewing Activity and Rumen Dynamics}

Chewing Activity. Cows were monitored for chewing activity following the methods of Mitlöhner et al. (2001) modified for 2 continuous 24-h periods (d 16 at $0800 \mathrm{~h}$ to $\mathrm{d} 17$ at $0800 \mathrm{~h}$ and $\mathrm{d} 17$ at $0800 \mathrm{~h}$ to $\mathrm{d} 18$ at $0800 \mathrm{~h}$ ) of each period by digital video recording. A surveillance camera (model 2531R, Ultra Pro Series B/W 1/3" CCD DSP camera equipped with a 1/3" 5-50 mm DC F1.7 CS-mount lens; Central Alarm Systems Inc., Littleton, $\mathrm{CO}$ ) and a digital image documentation and analysis system (DiGiCam 3016 port Remote Surveillance and Digital Recoding Package, version 7.1; Central Alarm Systems Inc., Littleton, CO) were used. Digital images were reviewed in 10-min intervals and chewing activity of each cow was defined as eating or ruminating. No chewing observations were made while the cows were held in the holding pen or milked in the parlor (approximately $90 \mathrm{~min} / \mathrm{d}$ ). Total time in minutes 
spent on each activity for each day was quantified by multiplying the total number of observations for that activity by $10 \mathrm{~min}$. Number of bouts and the length of each bout of eating and ruminating were recorded. A bout was defined as at least 2 consecutive observations of eating or ruminating behavior not interrupted by more than one observation of a different behavior.

Ruminal $\boldsymbol{p H}$. Ruminal $\mathrm{pH}$ was measured in ruminally fistulated cows (Bar Diamond, Parma, ID) with an indwelling ruminal $\mathrm{pH}$ measurement system (Penner et al., 2006; LRCpH, Dascor, Escondido, CA) at 30-s intervals for a 24 -h period (d 20 at $0930 \mathrm{~h}$ to d 21 at $0930 \mathrm{~h}$ ). Ruminal pH measurements were averaged over a 5-min period. Ruminal $\mathrm{pH}$ data were summarized as mean $\mathrm{pH}$ and the area that the $\mathrm{pH}$ curve was below a $\mathrm{pH}$ of 5.8 following the methods of Bauer et al. (1995).

Ruminal VFA. Samples of ruminal fluid (approximately $250 \mathrm{~mL}$ ) were collected from $30.5 \mathrm{~cm}$ beneath the ruminal digesta mat in the ventral sac at 4-h intervals for $24 \mathrm{~h}$ on d 20 (0930, 1330, 1730, and 2130 h) and d 21 (0130 and 0530 h) of each period. Samples were strained through 4 layers of cheesecloth. A portion of each sample of ruminal fluid (approximately $40 \mathrm{~mL}$ ) was frozen and stored at $-20^{\circ} \mathrm{C}$ until VFA determination (Bulletin 856B; Supelco Inc., Bellefonte, $\mathrm{PA})$. The concentration of VFA was determined by gas chromatography with use of a Varian CP-3800 gas chromatograph (Varian Inc., Palo Alto, CA) equipped with a flame-ionization detector and a 80/120 Carbopack B-DA/4\% Carbowax 20M column (Supelco Inc.).

Estimation of Microbial Protein Supply. Urinary excretion of purine derivatives (allantoin and uric acid) was used to estimate microbial N supply (Valadares et al., 1999). Microbial N supply was determined from urine spot samples collected on d 18 and 19 between 1400 to $1600 \mathrm{~h}$. A 40-mL urine sample was collected via manual stimulation of the vulva, and a portion of urine was immediately diluted (1:10) with $0.036 \mathrm{~N} \mathrm{H}_{2} \mathrm{SO}_{4}$ and stored at $-20^{\circ} \mathrm{C}$ for later analysis of allantoin (Chen et al., 1990). A 3-mL aliquot of urine was shipped with ice packs overnight to the Animal Diagnostic Center, Cornell University (Ithaca, NY), for analysis of creatinine (creatinine kit; Roche Diagnostics Corp., Indianapolis, IN) and uric acid (uric acid plus kit; Roche Diagnostics Corp.) with a chemistry analyzer (Hitachi 917; Roche Diagnostics Corp.).

\section{Total-Tract Digestibility}

Total-tract digestibility of DM, OM, CP, ADF, NDF, cellulose, hemicellulose, and starch were determined on d 17 to 21 of each period. Samples of diets (d 17 to 20 ) and orts (d 18 to 21) were collected. Fecal grab samples were collected on d 18 to 21 of each period so that every $3 \mathrm{~h}$ in a 24 -h period were represented (8 samples total). Fecal samples from each cow were composited by combining approximately $100 \mathrm{~g}$ of feces from each time point. Samples of diets, orts, and feces were frozen at $-20^{\circ} \mathrm{C}$, dried in a forced-air oven at $60^{\circ} \mathrm{C}$ for $48 \mathrm{~h}$, ground to pass through a 1-mm screen (Wiley mill; Arthur H. Thomas, Philadelphia, PA), and submitted for wet chemistry analysis (Cumberland Valley Analytical Services Inc., Hagerstown, MD). Composite samples (by cow) of diets, orts, and feces were analyzed for DM, ash, CP, ADF, NDF, lignin, and starch. Undigested NDF was used as an internal marker. Undigested NDF in diets, orts, and feces were quantified as NDF content of samples following an in vitro fermentation (Ankom Technology Corp., Fairport, NY) in buffered rumen media (Goering and Van Soest, 1970) for 120 h. Total tract digestibility was calculated by the ratio technique using the concentrations of the nutrients and undigested NDF in the diet and feces (Maynard et al., 1979). The nutrient content of the diet used in the digestibility calculation was adjusted for each cow based on the nutrient composition of the diet offered and refused. A calculated nutrient content of the consumed diet was used.

\section{Feed Analysis}

Individual feed ingredients were collected weekly and dried in a forced-air oven at $105^{\circ} \mathrm{C}$ for 18 to $24 \mathrm{~h}$ for DM determination to maintain dietary DM content throughout the duration of the study. Diets were adjusted weekly for changes in the DM content of the ensiled forages. Samples of diets (d 17 to 20), orts (d 18 to 21), and individual feed ingredients (d 17 to 20) were collected, frozen at $-20^{\circ} \mathrm{C}$, composited by period, and analyzed during 2007 for chemical composition using AOAC International (2000, 2006)-approved methods (CPM Plus; Cumberland Valley Analytical Services Inc.).

Particle Size Distribution and Physical Effectiveness Factor. Forage and diet composite samples were used to determine particle size distribution (as-fed basis) and physical effectiveness factor (pef $_{\text {Z-box }}$; DM basis) using ZEN-NOH/Miner Institute Particle Separator (Z-box; Cotanch et al., 2006). The resultant pef box value was used to calculate the physically effective neutral detergent fiber (peNDF) by multiplication of NDF content and pef $f_{\text {Zbox }}$ value (Mertens, 1997).

In Vitro Digestibility. In vitro starch digestibility (6-h) was determined for diet, corn silage, and corn meal composite samples ground to $4 \mathrm{~mm}$ (Cumberland Valley Analytical Services Inc.). Rumen starch ferment- 
Table 3. Analyzed chemical composition of low-, medium-, and high-starch diets fed to lactating Holstein cows

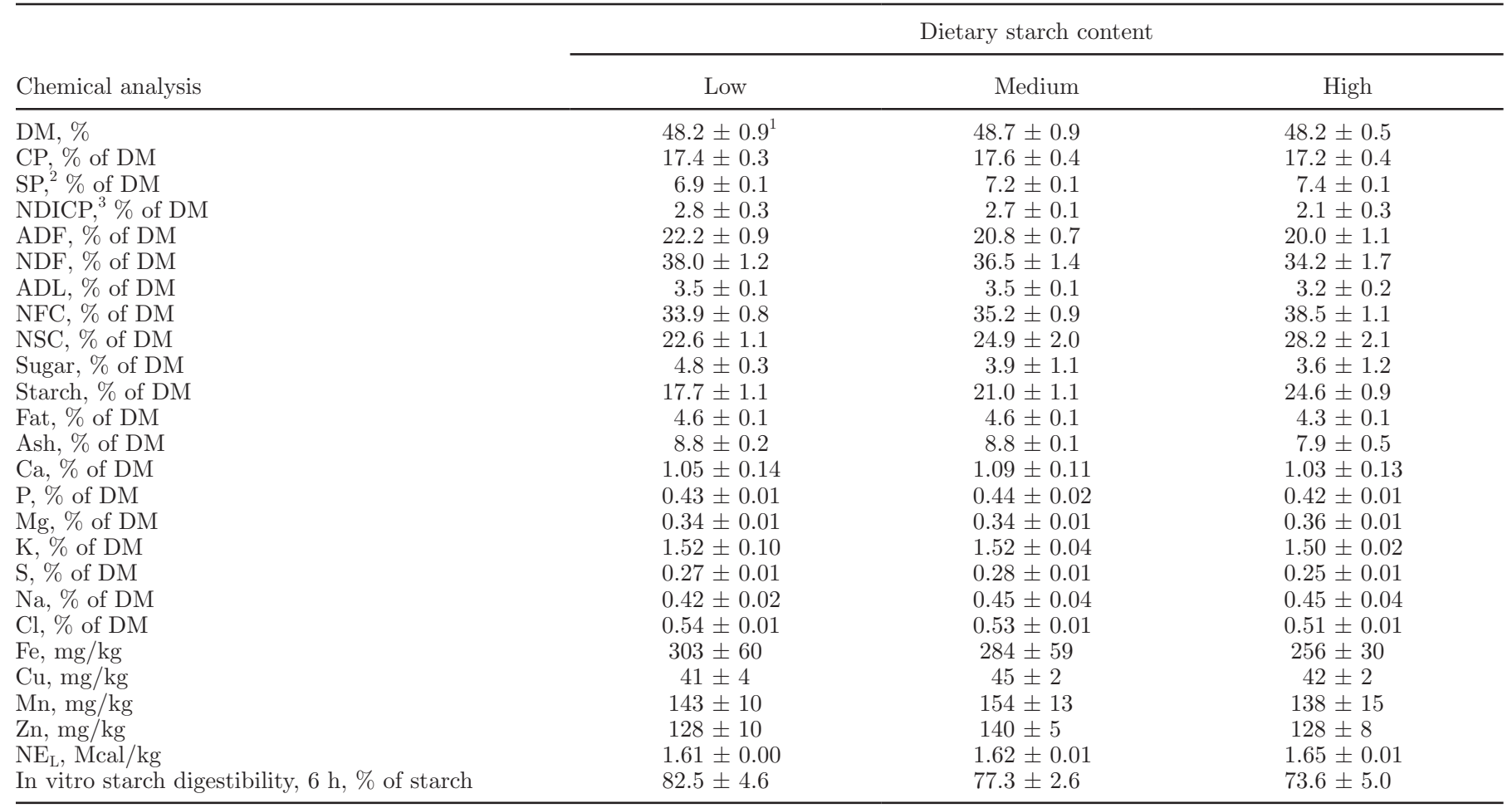

${ }^{1}$ Data are presented as the mean of 3 samples \pm associated SE.

${ }^{2} \mathrm{SP}=$ soluble protein.

${ }^{3}$ Neutral detergent insoluble CP.

ability was calculated as the product of in vitro starch digestibility (6-h) and dietary starch content. In vitro digestibility of NDF (24-h) of forage composite samples was determined using an in vitro fermentation (Daisy ${ }^{\text {II }}$ Incubator; Ankom Technology Corp.) in buffered media containing ruminal fluid (Goering and Van Soest, 1970).

\section{Statistical Analysis}

Data for DMI, milk yield and composition, BW, BCS, chewing activity, total tract nutrient digestibility, and microbial $\mathrm{N}$ were analyzed as a replicated Latin square design with model effects for diet, period, and replicate using the MIXED procedure of SAS (version 9.1, SAS Institute Inc., Cary, NC). Cow within replicate was a random effect. Repeated measurements of performance data were reduced to period means for each cow before statistical analysis. Data for ruminal $\mathrm{pH}$ and VFA were analyzed as a single Latin square design with repeated measures using the MIXED procedure of SAS. The model included the effects of diet, period, time, and the interaction of diet and time. Cow was a random effect. Least squares means were separated using Tukey's procedure when a significant F-test $(P<0.05)$ was detected.

\section{RESULTS AND DISCUSSION}

\section{Experimental Diets}

As analyzed, dietary starch content was $17.7 \%$ (LS), $21.0 \%$ (MS), and $24.6 \%$ (HS; Table 3). The 6-h starch digestibility of the TMR was $82.5 \%$ (LS), $77.3 \%$ (MS), and $73.6 \%$ (HS). The greater starch digestibility, as dietary starch content decreased, reflects the higher starch digestibility of the concentrate mix containing wheat middlings and other NFFS (90.8\%) compared with the corn meal (57.3\%; Tables 2 and 3 ) in addition to the greater portion of starch being provided by corn silage. The rumen-fermentable starch was 18.1 (LS), 16.2 (MS) and $14.6 \%$ (HS). The range between HS and LS in rumen-fermentable starch (3.5 percentage units) was substantially less than the range in starch content (6.9 percentage units). Aside from starch content and fermentability, the diet nutrient analysis (Table 3) as well as as-fed particle size distributions of diet ingredients were within normal ranges (Table 4) and diets were similar (Table 5). Therefore, any animal response to the experimental TMR should be due to differences in starch content or fermentability. 


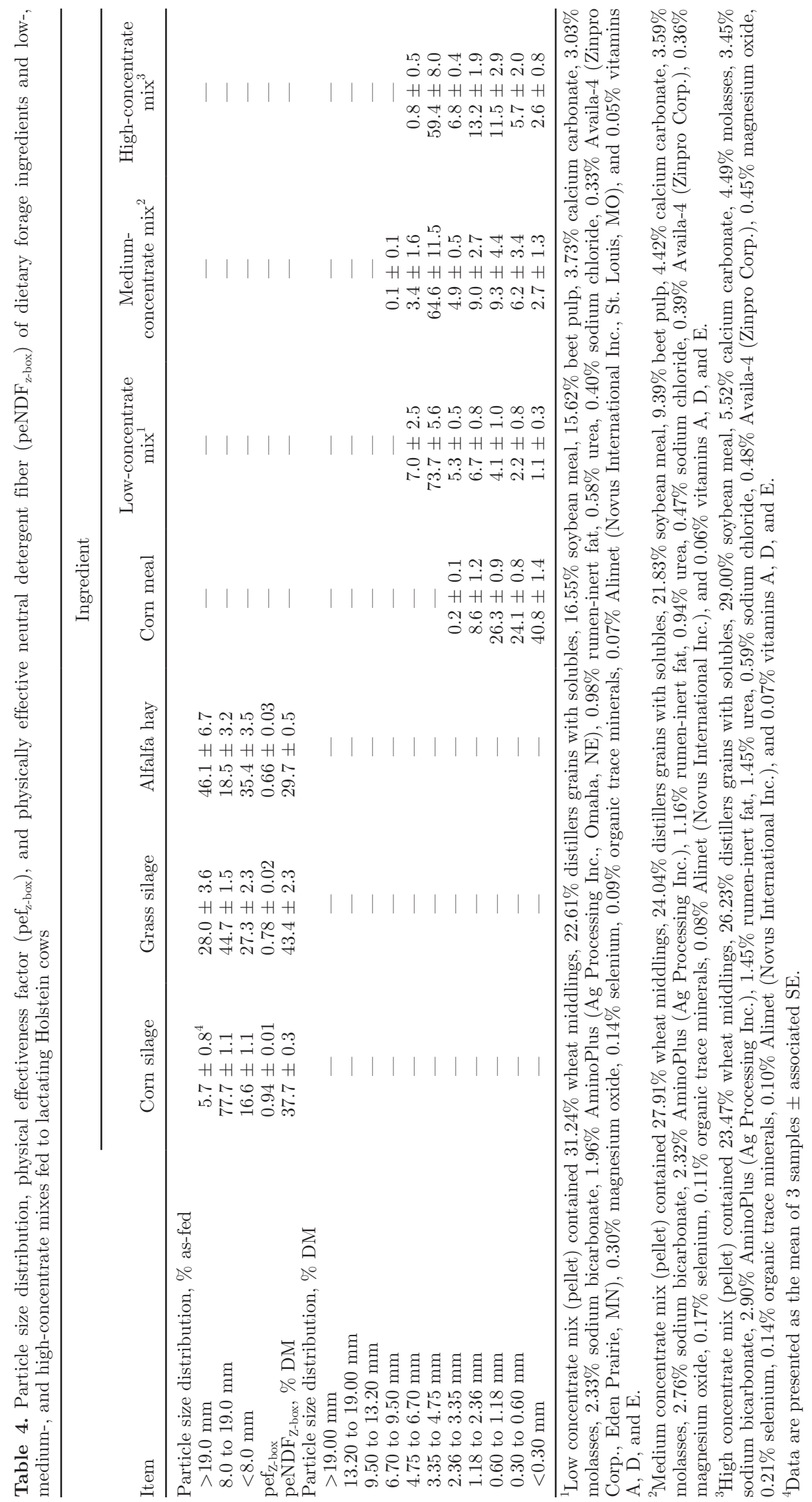


Table 5. Particle size distribution, physical effectiveness factor, and physically effective neutral detergent fiber of low-, medium-, and high-starch diets fed to lactating Holstein cows

\begin{tabular}{lccc}
\hline & \multicolumn{3}{c}{ Dietary starch content } \\
\cline { 2 - 4 } Item & Low & Medium & High \\
\hline Particle size distribution, \% as-fed & & & \\
$>19.0 \mathrm{~mm}$ & $8.2 \pm 0.1^{1}$ & $8.0 \pm 0.5$ & $8.4 \pm 1.1$ \\
8.0 to $19.0 \mathrm{~mm}$ & $39.6 \pm 2.9$ & $39.7 \pm 3.2$ & $39.2 \pm 1.8$ \\
$<8.0 \mathrm{~mm}$ & $52.2 \pm 2.9$ & $52.3 \pm 3.7$ & $52.3 \pm 2.0$ \\
pef $_{\text {Z-box }}$ peNDF $_{\text {Z-box }},{ }^{3} \% \mathrm{DM}$ & $0.63 \pm 0.01$ & $0.61 \pm 0.03$ & $0.59 \pm 0.01$ \\
\hline
\end{tabular}

${ }^{1}$ Data are presented as the mean of 3 samples \pm associated SE.

${ }^{2}$ pef = physically effective fiber; determined by the ZEN-NOH/Miner Institute Particle Separator (Z-box).

${ }^{3}$ peNDF $=$ physically effective neutral detergent fiber; product of neutral detergent fiber content and pef ${ }_{\text {Z-box }}$ of the diet (Mertens, 1997).

\section{Lactation Performance}

Short-term responses in DMI, BW change, BCS change, milk yield, and milk component production were unaffected $(P>0.10)$ by dietary starch content (Table 6). A reduction $(P=0.04)$ in MUN was noted as dietary starch content increased, although the difference $(13.3 \mathrm{mg} / \mathrm{dL}$ for HS vs. 14.6 and $14.8 \mathrm{mg} / \mathrm{dL}$ for LS and MS, respectively) was small and likely of little biological significance. Nonetheless, a lower starch diet
(22 vs. $27 \%$ starch; Ferraretto et al., 2011) fed to cows of similarly high DMI and milk production $(>26 \mathrm{~kg} / \mathrm{d}$ of DMI and $45 \mathrm{~kg} / \mathrm{d}$ of milk) also resulted in slightly lower MUN concentrations for cows fed lower-starch diets. Higher MUN for the LS diet compared with MS and HS diets may be related to a lower intake of starch that compromises ruminal microbial $\mathrm{CP}$ production (Oba and Allen, 2003). However, we did not observe any influence $(P>0.10)$ of dietary starch on ruminal production of microbial CP in our study, possibly sug-

Table 6. Lactational performance of lactating Holstein cows fed low-, medium-, and high-starch diets

\begin{tabular}{|c|c|c|c|c|c|}
\hline \multirow[b]{2}{*}{ Item } & \multicolumn{3}{|c|}{ Dietary starch content } & \multirow[b]{2}{*}{ SEM } & \multirow{2}{*}{$\frac{P \text {-value }}{\text { Diet }}$} \\
\hline & Low & Medium & High & & \\
\hline DMI, kg/d & 26.4 & 26.9 & 26.3 & 0.8 & 0.51 \\
\hline DMI, $\%$ of BW & 3.68 & 3.72 & 3.65 & 0.10 & 0.60 \\
\hline $\mathrm{BW}, \mathrm{kg}$ & 718 & 725 & 722 & 16 & 0.27 \\
\hline BW change, $\mathrm{kg} / 21 \mathrm{~d}$ & 6 & 11 & 7 & 4 & 0.66 \\
\hline BCS & 2.90 & 2.83 & 2.95 & 0.13 & 0.12 \\
\hline BCS change, unit/21 d & -0.04 & -0.12 & 0.00 & 0.06 & 0.34 \\
\hline Milk, kg/d & 42.9 & 43.4 & 44.1 & 1.9 & 0.60 \\
\hline $3.5 \% \mathrm{FCM}, \mathrm{kg} / \mathrm{d}^{1}$ & 43.1 & 43.4 & 43.8 & 1.8 & 0.86 \\
\hline $\mathrm{SCM}, \mathrm{kg} / \mathrm{d}^{1}$ & 40.3 & 40.8 & 41.3 & 1.6 & 0.73 \\
\hline \multicolumn{6}{|l|}{ Milk component yield } \\
\hline Fat, $\mathrm{kg} / \mathrm{d}$ & 1.50 & 1.50 & 1.47 & 0.08 & 0.90 \\
\hline True protein, $\mathrm{kg} / \mathrm{d}$ & 1.31 & 1.35 & 1.33 & 0.06 & 0.75 \\
\hline Lactose, $\mathrm{kg} / \mathrm{d}$ & 2.04 & 2.09 & 2.07 & 0.10 & 0.85 \\
\hline $\mathrm{SNF}, \mathrm{kg} / \mathrm{d}$ & 3.76 & 3.83 & 3.79 & 0.17 & 0.84 \\
\hline \multicolumn{6}{|l|}{ Milk component } \\
\hline Fat, $\%$ & 3.57 & 3.57 & 3.48 & 0.15 & 0.45 \\
\hline True protein, \% & 3.09 & 3.18 & 3.14 & 0.07 & 0.19 \\
\hline Lactose, $\%$ & 4.81 & 4.82 & 4.85 & 0.05 & 0.43 \\
\hline $\mathrm{SNF}, \%$ & 8.84 & 8.94 & 8.92 & 0.08 & 0.13 \\
\hline MUN, mg/dL & $14.6^{\mathrm{a}}$ & $14.8^{\mathrm{a}}$ & $13.3^{\mathrm{b}}$ & 0.7 & 0.04 \\
\hline SCS & 2.26 & 2.27 & 2.23 & 0.56 & 0.99 \\
\hline \multicolumn{6}{|l|}{ Efficiency, ${ }^{2} \mathrm{~kg} / \mathrm{kg}$} \\
\hline Milk/DMI & 1.64 & 1.62 & 1.68 & 0.08 & 0.32 \\
\hline $3.5 \% \mathrm{FCM} / \mathrm{DMI}$ & 1.64 & 1.61 & 1.67 & 0.05 & 0.48 \\
\hline $\mathrm{SCM} / \mathrm{DMI}$ & 1.53 & 1.52 & 1.57 & 0.05 & 0.41 \\
\hline
\end{tabular}


Table 7. Chewing activity data of lactating Holstein cows fed low-, medium-, and high-starch diets

\begin{tabular}{|c|c|c|c|c|c|}
\hline \multirow[b]{2}{*}{ Item } & \multicolumn{3}{|c|}{ Dietary starch content } & \multirow[b]{2}{*}{ SEM } & \multirow{2}{*}{$\frac{P \text {-value }}{\text { Diet }}$} \\
\hline & Low & Medium & High & & \\
\hline $\begin{array}{l}\text { Total chewing } \\
\mathrm{min} / \mathrm{d}\end{array}$ & 809 & 825 & 810 & 23 & 0.73 \\
\hline $\begin{array}{l}\text { Eating } \\
\mathrm{min} / \mathrm{d}\end{array}$ & 283 & 288 & 284 & 16 & 080 \\
\hline Bouts & 6.6 & 6.5 & 6.0 & 0.3 & $\begin{array}{l}0.09 \\
0.35\end{array}$ \\
\hline Bout length, min & 44 & 45 & 47 & 4 & 0.59 \\
\hline Ruminating & & & & & \\
\hline $\min / \mathrm{d}$ & 526 & 537 & 527 & 19 & 0.80 \\
\hline Bouts & 11.9 & 12.1 & 11.7 & 0.4 & 0.73 \\
\hline Bout length, min & 44 & 45 & 44 & 2 & 0.87 \\
\hline
\end{tabular}

gesting a change in protein fraction pool sizes which corresponds with the change in starch.

Efficiency of milk production (SCM/DMI) was similar among diets $(P>0.10$; Table 6$)$. Some previous studies have observed reductions in efficiency when lower starch diets were fed (e.g., Ferraretto et al., 2011), but others have found no effect of starch content on efficiency (e.g., Gencoglu et al., 2010). A meta-analysis reported by Ferraretto et al. (2013) determined that DMI was not altered by dietary starch content, milk yield increased by $0.08 \mathrm{~kg} / \mathrm{d}$ for every percentage unit increase in dietary starch; however, this did not result in altered efficiency of feed conversion. Replacement of the rapidly fermentable carbohydrates provided by corn grain with fermentable carbohydrates from NFFS has resulted in little alteration in milk or milk component production (Voelker Linton and Allen, 2007; Gencoglu et al., 2010). In summary, substitution of wheat middlings and beet pulp for corn grain resulted in similar lactational performance for cows at high DMI and milk production levels.

\section{Chewing Activity, Ruminal Fermentation, and Total-Tract Digestibility}

No effect $(P>0.10)$ of diet on eating and ruminating activities was noted (Table 7). The amount of chewing activity observed for all diets indicated that they were adequate in peNDF (Mertens, 1997) and averaged $36.9 \%$ across diets (Tables 4 and 5). Providing sufficient peNDF supports normal ruminal function due to longer forage particles enhancing chewing during eating and ruminating, salivary buffer secretion (Beauchemin, 1991; Mertens, 1997), and formation of a functional ruminal digesta mat. Maintaining sufficient dietary peNDF is important for ensuring ruminal conditions that promote efficient carbohydrate fermentation (Beauchemin, 1991; Mertens, 1997).

No effects $(P>0.10)$ of diet on ruminal $\mathrm{pH}$, total VFA concentration, or acetate-to-propionate ratio were observed (Table 8). Interestingly, butyrate concentration decreased as dietary starch content increased. Previous research (Vallimont et al., 2004) suggests that

Table 8. Ruminal fermentation data of lactating Holstein cows fed low-, medium-, and high-starch diets

\begin{tabular}{|c|c|c|c|c|c|c|c|}
\hline \multirow[b]{2}{*}{ Item } & \multicolumn{3}{|c|}{ Dietary starch content } & \multirow[b]{2}{*}{ SEM } & \multicolumn{3}{|c|}{$P$-value } \\
\hline & Low & Medium & High & & Diet (D) & Time $(\mathrm{T})$ & $\mathrm{D} \times \mathrm{T}$ \\
\hline Ruminal pH & 6.10 & 6.01 & 6.07 & 0.12 & 0.76 & 0.002 & 0.13 \\
\hline Area $^{1}<5.8$ & 1.29 & 1.61 & 1.75 & 0.52 & 0.74 & - & - \\
\hline Total VFA, m $M$ & 151.8 & 153.4 & 145.2 & 6.0 & 0.21 & $<0.001$ & 0.66 \\
\hline \multicolumn{8}{|c|}{ Individual VFA, $\mathrm{mM}$} \\
\hline Acetate $(\mathrm{A})$ & 87.0 & 85.8 & 87.1 & 3.5 & 0.94 & $<0.001$ & 0.99 \\
\hline Propionate $(\mathrm{P})$ & 38.6 & 38.3 & 34.5 & 2.9 & 0.51 & $<0.001$ & 0.86 \\
\hline Butyrate (B) & $19.5^{\mathrm{a}}$ & $18.9^{\mathrm{ab}}$ & $17.4^{\mathrm{b}}$ & 1.1 & 0.01 & $<0.001$ & 0.31 \\
\hline Isobutyrate & 1.2 & 1.2 & 1.2 & 0.1 & 0.95 & 0.37 & 0.52 \\
\hline Valerate & 4.0 & 4.4 & 3.6 & 0.5 & 0.50 & 0.002 & 0.81 \\
\hline Isovalerate & 1.4 & 1.6 & 1.3 & 0.2 & 0.12 & $<0.001$ & 0.68 \\
\hline $\mathrm{A}: \mathrm{P}$ & 2.3 & 2.3 & 2.6 & 0.3 & 0.70 & $<0.001$ & 0.88 \\
\hline$(\mathrm{A}+\mathrm{B}): \mathrm{P}$ & 2.8 & 2.9 & 3.1 & 0.3 & 0.80 & $<0.001$ & 0.51 \\
\hline Microbial N, g/d & 579 & 590 & 583 & 24 & 0.75 & - & - \\
\hline
\end{tabular}

$\overline{\mathrm{a}, \mathrm{b}}$ Least squares means within a row without a common superscript differ $(P<0.05)$.

${ }^{1}$ Area $<5.8=$ ruminal $\mathrm{pH}$ units below 5.8 by $\mathrm{h}$. 
Table 9. Total tract nutrient digestibility of lactating Holstein cows fed low, medium, and high starch diets

\begin{tabular}{lccccc}
\hline \multirow{2}{*}{$\begin{array}{l}\text { Total tract } \\
\text { digestibility, \% }\end{array}$} & \multicolumn{3}{c}{ Dietary starch content } & & P-value \\
\cline { 2 - 4 } \cline { 5 - 6 } & Low & Medium & High & SEM & Diet \\
\hline DM & $64.5^{\mathrm{b}}$ & $64.8^{\mathrm{b}}$ & $67.1^{\mathrm{a}}$ & 0.6 & 0.004 \\
OM & $67.0^{\mathrm{b}}$ & $67.3^{\mathrm{b}}$ & $69.2^{\mathrm{a}}$ & 0.5 & 0.009 \\
CP & 66.8 & 66.4 & 68.1 & 0.9 & 0.21 \\
ADF & 42.4 & 40.6 & 42.2 & 1.4 & 0.60 \\
NDF & 43.7 & 43.4 & 42.3 & 1.2 & 0.62 \\
Cellulose & 49.6 & 47.4 & 49.4 & 1.5 & 0.51 \\
Hemicellulose & 45.4 & 46.7 & 42.4 & 1.5 & 0.10 \\
Starch & 98.2 & 98.3 & 98.5 & 0.1 & 0.25 \\
\hline
\end{tabular}

a,b Least squares means within a row without a common superscript differ $(P<0.05)$.

higher dietary sugar content may increase butyrate production in vitro due to proliferation of Butyrivibrio fibrisolvens or other butyrate-producing microbes. In our study, as starch content decreased, sugar content of the TMR increased slightly which reflected substitution of NFFS for corn grain. Overall, the ruminal conditions observed across all TMR (average $\mathrm{pH}>6.0$, approximately $2 \mathrm{~h} / \mathrm{d} \mathrm{pH}<5.8$, total VFA concentration $>145 \mathrm{~m} M$, and acetate-to-propionate ratio $>2.5$ ) were supportive of efficient microbial fermentation of carbohydrates and microbial CP synthesis (Firkins et al., 2001; Voelker and Allen, 2003b).

Reducing dietary starch had no effect $(P>0.10)$ on microbial $\mathrm{N}$ production (Table 8). This was not surprising given that ruminal $\mathrm{pH}$ and fermentation were unaffected as well. Microbial N production was high across all diets, but was realistic for cows consuming high levels of DM and producing greater than 40 $\mathrm{kg} / \mathrm{d}$ of milk. Results from an in vitro study suggest the flow of microbial $\mathrm{N}$ is greater for cornstarch when compared with that of fiber or corn dextrose (Hristov et al., 2005). Together these data suggest that alteration of the carbohydrate fraction in the rumen may result in altered ammonia $\mathrm{N}$ concentration but result in unaltered microbial $\mathrm{N}$ flow.

In an in vitro evaluation of ruminal microbial growth with various carbohydrate sources, Hall and Herejk (2001) concluded that starch was most effective at promoting microbial growth, whereas sucrose and pectin were approximately $88 \%$ as effective, but still quite acceptable energy sources. Neutral detergent fiber was least effective at promoting microbial growth, but the amount of growth would be a function of the digestibility of the NDF. In our study, the range in ruminal starch fermentability was relatively narrow and ruminal starch fermentability was high among diets, whereas the forages had high in vitro 24-h NDF digestibilities, indicating that total fermentability of carbohydrates was maintained among all diets regardless of dietary starch content.
Total tract DM $(P<0.004)$ and $\mathrm{OM}(P<0.009)$ digestibility increased as dietary starch content increased (Table 9), although the range was small (67.0 to $69.2 \%$ for OM digestibility). The expected greater digestibility of the higher-starch diets explains the greater measured OM digestibility, but the increased total tract OM digestibility was not of sufficient magnitude to influence short-term DMI or milk production. No differences $(P>0.10)$ among diets in total tract NDF or starch digestibility were observed, and the measured digestibility coefficients were high and typical of diets commonly fed to high-producing dairy cows (NRC, 2001).

Few studies have explicitly evaluated the effect of feeding various sources of ruminally fermentable carbohydrates on actual dairy cow performance. Although the cows only averaged approximately $20 \mathrm{~kg} / \mathrm{d}$ of milk production, Hindrichsen et al. (2006) evaluated 6 concentrate mixes containing several alternative feeds in a diet with a 1:1 forage-to-concentrate ratio (DM basis). Soybean hulls, apple pomace, Jerusalem artichokes, molasses, and wheat were used to formulate diets with the following ranges in carbohydrate composition: starch $=5.4$ to $20.4 \%$ of dietary DM; sugars $=3.8$ to $11.4 \%$; fructans $=1.4$ to $12.0 \%$; pectin $=2.4$ to $5.3 \%$; and $\mathrm{NDF}=31.9$ to $51.8 \%$. Despite the wide range in the carbohydrate composition of these diets, the resulting feed intake, ECM yield, and the $\mathrm{NE}_{\mathrm{L}}$ content of these diets (based on measured nutrient digestibility) were all similar. When these results are combined with the unaltered lactational performance of our study, it suggests that rumen microbes can use other carbohydrates, such as digestible fiber and sugars, as an energy source for high milk production even with diets lower in starch than those commonly fed. Our LS diet contained $17.7 \%$ starch, which supported similarly high DMI, SCM yield, and SCM/DMI compared with MS and HS diets, suggesting starch content may be reduced in rations of lactating dairy cows. 


\section{CONCLUSIONS}

Dietary starch content ranging between 17.7 and $24.6 \%$ of dietary DM had no measurable effect on shortterm feed intake, milk component production, ruminal fermentation, or microbial protein production responses for cows producing in excess of $40 \mathrm{~kg} / \mathrm{d}$ of SCM. Use of a combination of wheat middlings and beet pulp in place of corn grain maintained lactational performance similar to higher-starch diets, and these lower-starch diets could be economically feasible rations when corn prices are higher than NFFS.

\section{ACKNOWLEDGMENTS}

The authors are grateful to the Miner Institute dairy farm staff, C. S. Ballard, M. P. Carter, J. W. Darrah, S. A. Flis, and H. M. Gauthier (Miner Agricultural Research Institute, Chazy, NY) for their assistance with this study.

\section{REFERENCES}

AOAC International. 2000. Official Methods of Analysis. 17th ed. AOAC Int., Gaithersburg, MD.

AOAC International. 2006. Official Methods of Analysis. 18th ed. AOAC Int., Gaithersburg, MD.

Bauer, M. L., D. W. Herold, R. A. Britton, R. A. Stock, T. J. Klopfenstein, and D. A. Yates. 1995. Efficacy of laidlomycin propionate to reduce ruminal acidosis in cattle. J. Anim. Sci. 73:3445-3454.

Beauchemin, K. A. 1991. Ingestion and mastication of feed. Vet. Clin. North Am. Food Anim. Pract. 7:439-463.

Blasi, D. A., G. Kuhl, and K. C. Behnke. 1995. Wheat and wheat coproducts: Composition, feeding value and storability. Pages 49-72 in Proc. 2nd Natl. Altern. Feed Symp., St. Louis, MO. USDA and Univ. of Missouri, Columbia.

Boddugari, K., R. J. Grant, R. Stock, and M. Lewis. 2001. Maximal replacement of forage and concentrate with a new wet corn milling product for lactating dairy cows. J. Dairy Sci. 84:873-884.

Bradford, B. J., and C. R. Mullins. 2012. Strategies for promoting productivity and health of dairy cattle by feeding nonforage fiber sources. J. Dairy Sci. 95:4735-4746.

Chase, L. E. 2007. Can we feed less starch to our cows? Pages 213-220 in Proc. Cornell Nutr. Conf. for Feed Manufac., Syracuse, NY. Cornell University, Ithaca, NY.

Chen, X. B., F. D. De, B. Hovell, E. R. Ørskov, and D. S. Brown. 1990. Excretion of purine derivatives by ruminants: Effect of exogenous nucleic acid supply on purine derivative excretion by sheep. Br. J. Nutr. 63:131-142.

Cotanch, K. W., R. J. Grant, C. S. Ballard, J. W. Darrah, H. M. Dann, and T. Takano. 2006. Development of an on-farm system to determine pef value of as fed forages and TMR. J. Dairy Sci. 89(Suppl. 1):373 (Abstr.).

Ferguson, J. D., D. T. Galligan, and N. Thomsen. 1994. Principal descriptors of body condition score in Holstein cows. J. Dairy Sci. 77:2695-2703.

Ferraretto, L. F., P. M. Crump, and R. D. Shaver. 2013. Effect of cereal grain type and corn grain harvesting and processing methods on intake, digestion, and milk production by dairy cows through a meta-analysis. J. Dairy Sci. 96:533-550.

Ferraretto, L. F., R. D. Shaver, M. Espineira, H. Gencoglu, and S. J. Bertics. 2011. Influence of a reduced-starch diet with or without exogenous amylase on lactation performance by dairy cows. J. Dairy Sci. 94:1490-1499.

Firkins, J. L., M. L. Eastridge, N. R. St-Pierre, and S. M. Noftsger. 2001. Effects of grain variability and processing on starch utilization by lactating dairy cattle. J. Anim. Sci. 79:E218-E238.

Gencoglu, H., R. D. Shaver, W. Steinberg, J. Ensink, L. F. Ferraretto, S. J. Bertics, J. C. Lopes, and M. S. Akins. 2010. Effect of feeding a reduced-starch diet with or without amylase addition on lactation performance in dairy cows. J. Dairy Sci. 93:723-732.

Goering, H. K., and P. J. Van Soest. 1970. Forage Fiber Analysis (Apparatus, Reagents, Procedures, and Some Applications). Agriculture Handbook No. 379. Agricultural Research Service-USDA, Washington, DC.

Hall, M. B., and C. Herejk. 2001. Differences among carbohydrates in yields of crude protein from in vitro fermentation with mixed ruminal microbes. J. Dairy Sci. 84(Suppl. 1):200 (Abstr.).

Hindrichsen, I. K., H. R. Wettstein, A. Machmüller, K. E. Back Knudsen, J. Madsen, and M. Kreuzer. 2006. Digestive and metabolic utilization of dairy cows supplemented with concentrates characterized by different carbohydrates. Anim. Feed Sci. Technol. 126:43-61.

Hristov, A. N., J. K. Ropp, K. L. Grandeen, S. Abedi, R. P. Etter, A. Melgar, and A. E. Foley. 2005. Effect of carbohydrate source on ammonia utilization in lactating dairy cows. J. Anim. Sci. 83:408-421.

Ipharraguerre, I. R., and J. H. Clark. 2003. Soyhulls as an alternative feed for lactating dairy cows: A review. J. Dairy Sci. 86:10521073.

Maynard, L. A., J. K. Loosli, H. F. Hintz, and R. G. Warner. 1979. Digestive processes in different species. Pages 21-46 in Animal Nutrition. McGraw-Hill Inc., New York, NY.

Mertens, D. R. 1997. Creating a system for meeting the fiber requirements of dairy cows. J. Dairy Sci. 80:1463-1481.

Mitlöhner, F. M., J. L. Morrow-Tesch, S. C. Wilson, J. W. Dailey, and J. J. McGlone. 2001. Behavioral sampling techniques for feedlot cattle. J. Anim. Sci. 79:1189-1193.

NRC. 2001. Nutrient Requirements of Dairy Cattle. 7th rev. ed. Natl. Acad. Press, Washington, DC.

Oba, M., and M. S. Allen. 2003. Effects of diet fermentability on efficiency of microbial nitrogen production in lactating dairy cows. J. Dairy Sci. 86:195-207.

Penner, G. B., K. A. Beauchemin, and T. Mutsvangwa. 2006. An evaluation of the accuracy and precision of a stand-alone submersible continuous ruminal $\mathrm{pH}$ measurement system. J. Dairy Sci. 89:2132-2140

USDA-Economic Research Service. 2013. Feed grains: Yearbook tables. Accessed May 18, 2013. http://www.ers.usda.gov/datafiles/ Feed_Grains_Yearbook_Tables/Domestic_and_International_ Prices/FGYearbookTable12.htm.

Valadares, R. F. D., G. A. Broderick, S. C. Valadares Filho, and M. K. Clayton. 1999. Effect of replacing alfalfa silage with high moisture corn on ruminal protein synthesis estimated from excretion of total purine derivatives. J. Dairy Sci. 82:2686-2696.

Vallimont, J. E., F. Bargo, T. W. Cassidy, N. D. Luchini, G. A. Broderick, and G. A. Varga. 2004. Effects of replacing dietary starch with sucrose on ruminal fermentation and nitrogen metabolism in continuous culture. J. Dairy Sci. 87:4221-4229.

Voelker, J. A., and M. S. Allen. 2003a. Pelleted beet pulp substituted for high-moisture corn: 1. Effects on feed intake, chewing behavior and milk production of lactating dairy cows. J. Dairy Sci. $86: 3542-3552$.

Voelker, J. A., and M. S. Allen. 2003b. Pelleted beet pulp substituted for high-moisture corn: 2. Effects on digestion and ruminal digestion kinetics in lactating dairy cows. J. Dairy Sci. 86:3553-3561.

Voelker Linton, J. A., and M. S. Allen. 2007. Nutrient demand affects ruminal digestion responses to a change in dietary forage concentration. J. Dairy Sci. 90:4770-4779. 